\title{
Continuous Phencyclidine Treatment Induces Schizophrenia-Like Hyperreactivity of Striatal Dopamine Release
}

\author{
Andrea Balla, M.S., Rajeth Koneru, B.S., John Smiley, Ph.D., Henry Sershen, Ph.D., \\ and Daniel C. Javitt, M.D., Ph.D.
}

Functional dopaminergic hyperactivity is a key feature of schizophrenia. Recent in vivo imaging studies have demonstrated greater striatal dopamine release in response to amphetamine challenge in schizophrenia subjects than in normal controls. N-methyl-D-aspartate (NMDA) receptors are known to play a prominent role in regulation of striatal dopamine release. In humans, NMDA antagonists induce a psychotic state that closely resembles schizophrenia. The present study investigates the degree to which chronic continuous administration of the NMDA antagonist phencyclidine (PCP) induces schizophrenia-like hyperreactivity of striatal dopamine release to amphetamine in rodents. Rats were treated with 10 or $15 \mathrm{mg} / \mathrm{kg} / \mathrm{d} P C P$ for two weeks by osmotic minipump, and striatal dopamine release to amphetamine challenge $(1 \mathrm{mg} / \mathrm{kg}$ ) was monitored by microdialysis. PCP-treated rats showed significant enhancement in amphetamine-induced dopamine release, along with significantly enhanced locomotor activity. These findings support the concept that NMDA receptor dysfunction may contribute to dopaminergic dysfunction in schizophrenia.

[Neuropsychopharmacology 25:157-164, 2001] (C) 2001 American College of Neuropsychopharmacology. Published by Elsevier Science Inc.
KEY WORDS: NMDA receptors; Glutamate; Amphetamine; Dopamine; Striatum

Schizophrenia is a widely prevalent neuropsychiatric disorder of unknown etiology. The most widely accepted neurochemical model of schizophrenia, the dopamine model, proposes that schizophrenia is associated with functional hyperactivity of brain dopaminergic systems (Stein and Wise 1971; Davis et al. 1991; Jentsch and Roth 1999). This model is supported by the observations that amphetamine and other dopaminer-

From the Program in Cognitive Neuroscience and Schizophrenia, Nathan Kline Institute for Psychiatric Research, (AB, RK, JS, HS, DCJ) Orangeburg, NY; and Department of Psychiatry, New York University School of Medicine, (HS, DCJ) New York, NY.

Address correspondence to: Daniel C. Javitt, M.D., Ph.D., Nathan Kline Institute for Psychiatric Research, 140 Old Orangeburg Road, Orangeburg, NY 10962.

Received July 7, 2000; revised January 2, 2001; accepted January 10, 2001. gic agents induce psychotic symptoms that closely resemble those of schizophrenia and that currently available antipsychotic agents function primarily by blocking dopamine (D2) receptors. Mechanisms underlying dopamine dysfunction in schizophrenia, however, remain obscure.

Over the past decade, increasing attention has been paid to alternative neurochemical conceptualizations of schizophrenia based upon the phencyclidine/N-methyl-D-aspartate (PCP/NMDA) model (Javitt 1987; Javitt and Zukin 1991). This hypothesis is based upon the observation that PCP and other dissociative anesthetictype psychotomimetics (e.g., ketamine, MK-801) induce symptoms that closely resemble those of schizophrenia but differ somewhat from the symptoms induced by amphetamine (Luby et al. 1959, 1962; Domino and Luby 1981). PCP and related agents induce their prominent psychotomimetic effects by blocking neurotransmission at NMDA-type glutamate receptors, suggesting that 
dysfunction or dysregulation of NMDA receptor (NMDAR)-mediated neurotransmission may play a prominent role in the disorder (Javitt et al. 1987; Javitt and Zukin 1991; Olney and Farber 1995; Newcomer et al. 1999; Jentsch and Roth 1999).

The present study investigates the degree to which continuous treatment with PCP leads to schizophrenialike disturbances in dopamine regulation. This issue has been complicated until recently by the relative paucity of information concerning endogenous dopamine levels in schizophrenia. Over the past several years, however, several studies using in vivo radioreceptor label studies have demonstrated significant striatal hyperreactivity to amphetamine-stimulated dopamine release in schizophrenia (Laruelle et al. 1996, 1999; Breier et al. 1997; Abi-Dargham et al. 1998). Enhanced striatal dopamine levels were also observed following ketamine administration in normal volunteers (Breier et al. 1998), supporting a potential role for NMDA receptors in dopamine hyperactivity in schizophrenia. Similar effects of acute administration of NMDA antagonists are observed in rodents (Hiramatsu et al. 1989; Lillrank et al. 1994; Yonezawa et al. 1995).

Given that schizophrenia is a chronic condition potentially arising from persistent dysfunction of NMDA receptor-mediated neurotransmission, continuous PCP administration provides a superior dosing paradigm than does acute administration (Sams-Dodd 1999; Jentsch et al. 1998). Further, continuous administration permits amphetamine-induced effects to be measured against a constant background PCP level. For the present study, rats were treated chronically with PCP, and dopamine response to amphetamine was measured in striatum using in vivo microdialysis to investigate the degree to which continuous PCP treatment leads to enhanced responsiveness to amphetamine challenge. PCP was administered by osmotic minipump to maintain as constant a level of PCP as possible, in order to model a persistent NMDA underactivity state.

Schizophrenia-like social withdrawal symptoms increase progressively during continuous PCP treatment in both rats (Sams-Dodd 1998) and monkeys (Linn et al. 1999), supporting the utility of the continuous treatment model. NMDA antagonists are reported to enhance amphetamine-induced locomotor activity following both acute (Sripada et al. 1998; Druhan et al. 1996; Turgeon and Roche 1999) and continuous (Jentsch et al. 1998) treatment, although contrary results have also been obtained (Gandolfi et al. 1992). For the present study, therefore, amphetamine-induced locomotor activity was monitored along with striatal dopamine release.

Two prior studies have investigated effects of acute administration of NMDA antagonists on amphetamineinduced striatal dopamine release. The first (Kashihara et al. 1991) found no effect of a dose of $0.5 \mathrm{mg} / \mathrm{kg}$ MK-
801 on striatal dopamine release induced by a dose of 4 $\mathrm{mg} / \mathrm{kg}$ methamphetamine. In contrast, a second study (Miller and Abercrombie 1996) found significant enhancement of striatal dopamine release induced by a dose of $2.0 \mathrm{mg} / \mathrm{kg}$ amphetamine by a dose of $0.5 \mathrm{mg} /$ $\mathrm{kg}$ MK-801, whereas a lower dose was ineffective, supporting a potential role of NMDA receptors in regulating rodent striatal dopamine release. Effects of continuous NMDA antagonist administration on basal and amphetamine-induced dopamine levels in striatum, however, have not been previously evaluated.

\section{MATERIALS AND METHODS}

\section{Animals}

Studies were carried out in accordance with the Guide for the Care and Use of Laboratory Animals as adopted and promulgated by the National Institutes of Health. Male Sprague-Dawley rats (150-200 g) were bred inhouse. Animals were maintained under a $10 \mathrm{~h} / 14 \mathrm{~h}$ dark/light cycle, and were allowed food and water ad libitum during the microdialysis procedure and during the nighttime locomotor activity measurements. Food was withdrawn during amphetamine challenge procedures. Three to nine animals were used per group.

\section{PCP Administration}

PCP hydrochloride (obtained from the National Institute of Drug Abuse) was dissolved in sterile physiological saline and administered via osmotic pump (ALZA Corporation, model 2ML4) implanted under the skin. Saline-filled pumps were used in control animals. The pumps were filled based on the animal weight at the start of the experiment to deliver 10 or $15 \mathrm{mg} / \mathrm{kg} / \mathrm{d}$ for 2-3 weeks. The implantation was carried under anesthesia with ketamine hydrochloride and acepromazine maleate 1:1 mixture $(1 \mu \mathrm{l} / \mathrm{g}$, i.m.).

\section{Microdialysis}

Microdialysis was performed 16-22 d following pump implantation. Animals were anaesthetized with chloral hydrate $(400 \mathrm{mg} / \mathrm{kg}$, i.p.) and mounted in a stereotaxic frame (David Kopf Instrument). A CMA 10 guide cannula (Carnegie Medicine) was implanted into dorsomedial striatum on the left. Implantation coordinates (AP: +1.00, L: 2.5, V: 4.00-6.00) were determined relative to bregma (Paxinos and Watson 1998). Cannulae were cemented to the skull using dental acrylic with embedded stainless steel bone screws.

The day following surgery, CMA 10 probes $(0.5 \mathrm{~mm} \times$ $2.0 \mathrm{~mm}$ membrane length with a molecular cut-off 20,000 Dalton) were inserted into the guide cannulae. The estimated recovery rate was $18-20 \%$. Probes were 
continuously perfused using a syringe pump CMA/100 (Carnegie Medicine) at a flow rate of $1.0 \mu \mathrm{l} / \mathrm{min}$ with a $\mathrm{Mg}^{2+}$-free Ringer solution containing $\mathrm{NaCl} 147 \mathrm{mM}$; $\mathrm{KCl} 4 \mathrm{mM} ; \mathrm{CaCl}_{2} 1.2 \mathrm{mM}$ (degassed). Two hours were allowed to establish the basal level of the extracellular catecholamines. Thirty-minute dialysate samples were collected with a fraction collector (Bioanalytical Systems). After three baseline samples, the rats were challenged with an amphetamine injection $(1 \mathrm{mg} / \mathrm{kg}$, s.c.). Dialysis samples were collected for an additional 210 minutes.

Following completion of the experiment, animals were anaesthetized with ketamine hydrochloride and acepromazine maleate 1:1 mixture $(1 \mu \mathrm{l} / \mathrm{g}$, i.m.). Blood samples were obtained via cardiac puncture, and plasma separated for PCP analysis. The rat brain was fixed first with $100 \mathrm{ml}$ of $0.9 \%$ saline in $0.1 \mathrm{M}$ phos- phate, $\mathrm{pH} 7.4$, and then with $300 \mathrm{ml}$ of ice cold $4 \%$ paraformaldehyde in $0.1 \mathrm{M}$ phosphate, $\mathrm{pH}$ 7.4. The brains were cryoprotected in $30 \%$ sucrose in $0.1 \mathrm{M}$ phosphate. The placement of the probes was determined histologically.

\section{Dopamine, DOPAC, and HVA Level Determinations}

Dopamine and dopamine metabolite levels were determined by high-pressure liquid chromatography with electrochemical detection (HPLC-EC) (BAS-480 system). The dialysate samples $(30 \mu \mathrm{l})$, collected in $0.1 \mathrm{~N}$ perchloric acid, were injected by autosampler (BAS Sample Sentinel) onto a microbore $C_{18} 100 \times 2 \mathrm{~mm}$ column. The samples were eluted with filtered, degassed mobile phase $\left(\mathrm{NaH}_{2} \mathrm{PO}_{4} 25 \mathrm{mM}\right.$; sodium citrate $50 \mathrm{mM}$; diso-
A

B

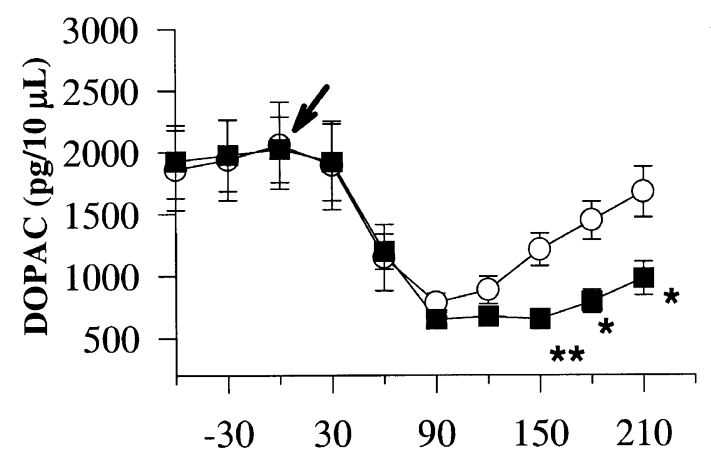

C

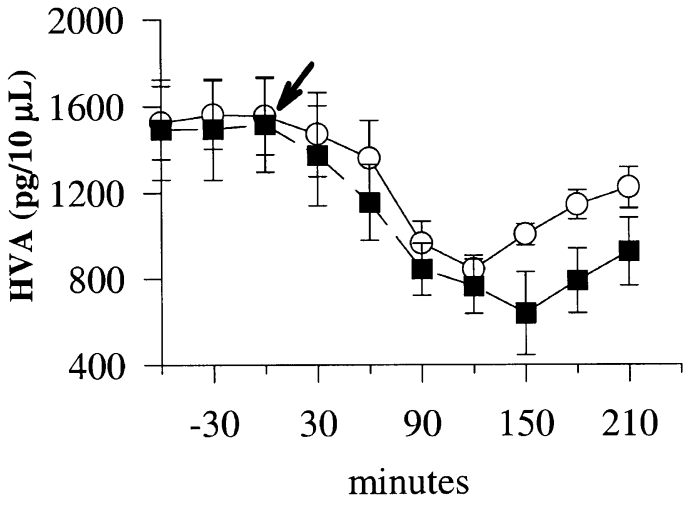

$15 \mathrm{mg} / \mathrm{kg} / \mathrm{day}$ PCP
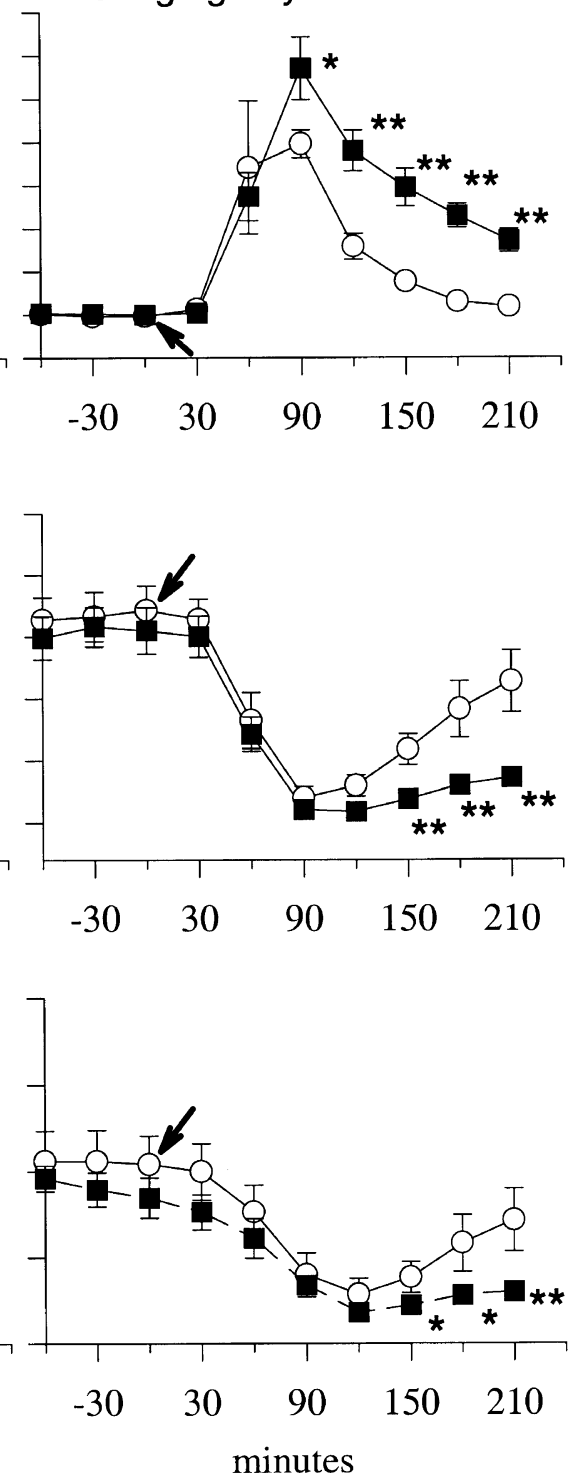

Figure 1. Amphetamineinduced alterations in dopamine, DOPAC, and HVA levels in animals that had been pretreated for two weeks PCP (filled square) or saline (open circle) at indicated doses. Amphetamine $(1 \mathrm{mg} / \mathrm{kg})$ was administered at time 0 (arrow). Data are mean \pm sem. ${ }^{*} p<.05$ vs. saline, ${ }^{* *} p<.01$ vs. saline. 
dium-EDTA $27 \mu \mathrm{M}$; diethylamine- $\mathrm{HCl} 10 \mathrm{mM}$; 1-octanesulfonic acid $\times 2.2 \mathrm{mM}$; methanol $3 \% \mathrm{v} / \mathrm{v}$; dimethylacetamide $2.1 \% \mathrm{v} / \mathrm{v} ; \mathrm{pH} 3.5$ ) at a flow rate $0.4 \mathrm{ml} / \mathrm{min}$. Classic glassy carbon electrodes (BAS) vs. $\mathrm{Ag} / \mathrm{AgCl}$ reference electrode at $0.60 \mathrm{~V}$ and $0.75 \mathrm{~V}$ and with sensitivity levels of 0.5 and $20 \mathrm{nA}$ were used for dopamine and DOPAC/HVA determinations, respectively. Retention times for DOPAC, dopamine and HVA were 3.8, 4.9, and $7.8 \mathrm{~min}$, respectively.

Data were acquired on a PC-compatible computer using BAS-5 interface. Standard curves were constructed using 7 points between 0.625 and $80 \mathrm{pg} / 10 \mu \mathrm{l}$ for dopamine, 23.4-3000 pg/10 $\mu \mathrm{l}$ for DOPAC, and 100-2000 pg/ $10 \mu \mathrm{l}$ for HVA. Correlations coeffecients (r) of $>0.98$ were obtained for all curves. The working standard solutions were stored at $-80^{\circ} \mathrm{C}$ and $10 \mu l$ of the standard solution was injected between biological samples.

\section{Locomotor Activity}

Spontaneous and amphetamine-induced locomotor activity (total activity counts) was monitored using an automated infrared beam-based system (Columbus Instrument Auto-Track). All testing was performed in animal's home cages. For assessment of spontaneous activity, animals were placed on activity monitors overnight, and activity was measured at 60-min intervals. For monitoring of amphetamine-induced activity, animals were placed on the monitors and baseline activity was monitored for $30 \mathrm{~min}$. Animals then received amphetamine ( $1 \mathrm{mg} / \mathrm{kg}$, s.c), following which activity was monitored for $210 \mathrm{~min}$. Spontaneous nighttime activity measurement were obtained pre-implantation and at one and two weeks following minipump insertion. Amphetamine-induced activity was monitored pre-implantation and following continuous (2 week) treatment with PCP or saline. Activity measures were obtained at least $48 \mathrm{hrs}$ prior to microdialysis studies.

\section{Data Analysis}

Primary dependent measures consisted of dopamine levels prior to and following amphetamine administration and amphetamine-induced locomotor activity. DOPAC and HVA levels and spontaneous nighttime activity served as additional explanatory variables. Data were analyzed using repeated measures ANOVA with Geisser-Greenhouse correction, with within subject measure of time following amphetamine injection (i.e., fraction or observation number) and between subject factor of drug (PCP or saline). Separate rmANOVA were conducted at each dose level. Significant main or interaction effects were followed up by between-group post-hoc t-test. All statistics are two-tailed with $\propto$ level of significance of $p<.05$. Data in text are mean \pm s.d.
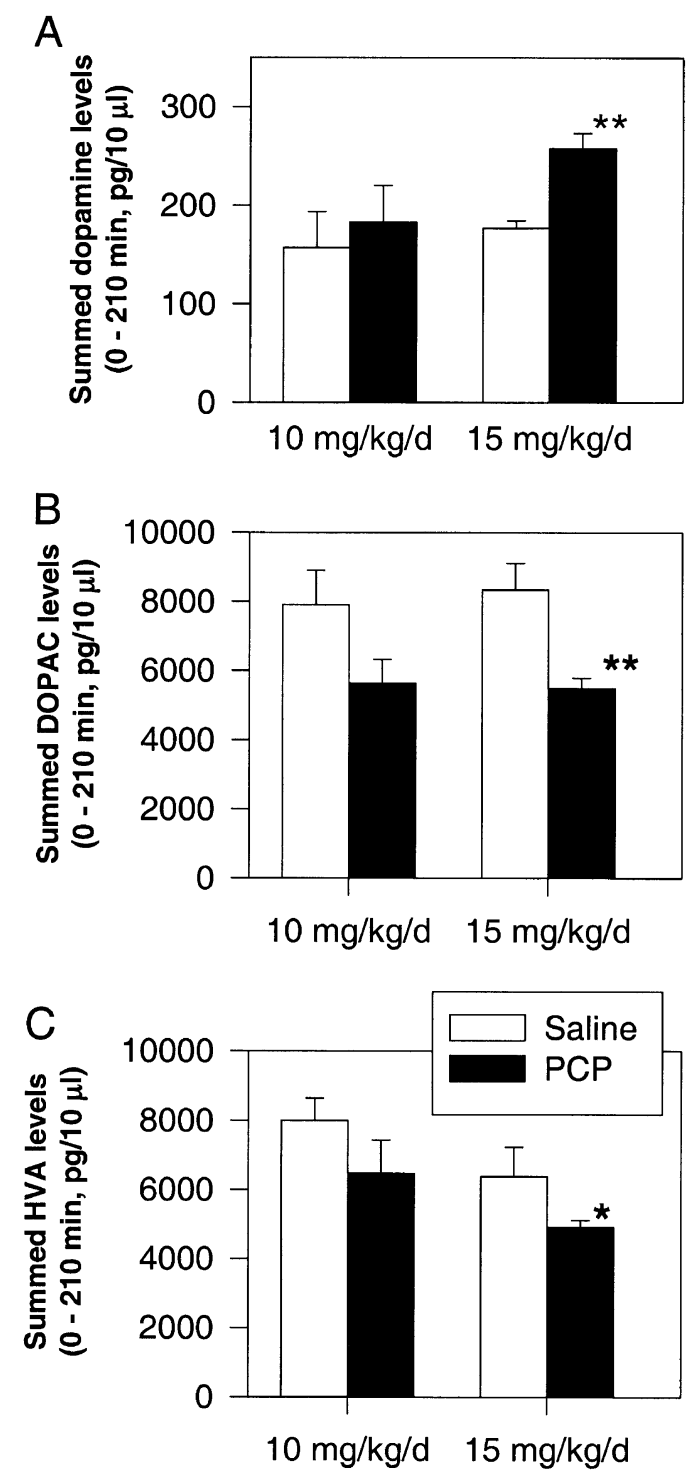

Figure 2. Integrated dopamine, DOPAC, and HVA levels during the 0-210 min. interval following administration of amphetamine. ${ }^{*} p<.05$ vs. saline, ${ }^{* *} p<.01$ vs. saline.

\section{RESULTS}

\section{Serum PCP Levels}

Serum levels following 10 and $15 \mathrm{mg} / \mathrm{kg} / \mathrm{d}$ treatment were $39.5 \pm 24.5$ and $72.0 \pm 11.6 \mathrm{ng} / \mathrm{ml}$, respectively. These levels are in the range associated with PCP-induced psychosis, catatonia, and agitation in humans (Walberg et al. 1983).

\section{Microdialysis}

In control animals, amphetamine administration led to significant 3-5-fold increase in microdialysate dopamine levels. Levels peaked at $90 \mathrm{~min}$ following amphetamine administration and returned to baseline by 210 
min (Figure 1A). Increased dopamine release was accompanied by significant reductions in extracellular DOPAC and HVA levels, consistent with known mechanism of amphetamine (Nishijima et al. 1996) (Figures $1 \mathrm{~B}$ and $1 \mathrm{C})$.

No significant alterations in baseline dopamine levels were observed following treatment with either 10 or $15 \mathrm{mg} / \mathrm{kg} / \mathrm{d}$ PCP (Figure 1A). Animals treated with 10 $\mathrm{mg} / \mathrm{kg} /$ day showed a small increase in dopamine level following amphetamine administration that was not statistically significant $(\mathrm{F}=0.2 \mathrm{df}=1,7, p=.7)$. Treatment with $15 \mathrm{mg} / \mathrm{kg} /$ day PCP led to a highly significant enhancement of amphetamine-stimulated release $(\mathrm{F}=10.9, \mathrm{df}=1,12, p=.006)$. A significant PCP treatment $\times$ time effect was also observed $(\mathrm{F}=7.74, \mathrm{df}=$ $1.9,72, p=.003)$, reflecting greater enhancement at later, than earlier, time points. Summed levels during the 0-210 min was significantly different between groups (Figure 2A). In post-hoc tests, significant elevations in dopamine levels were observed throughout the 60-210- $\mathrm{min}$ interval.

PCP treatment also did not affect baseline DOPAC or HVA levels (Figures 1B and 1C). However, PCP treatment significantly augmented amphetamine-induced reductions in microdialysate DOPAC levels in parallel with increased dopamine release (Figure 1B). A significant PCP treatment $\times$ time interaction was observed following treatment with $10 \mathrm{mg} / \mathrm{kg} / \mathrm{d}(\mathrm{F}=7.5, \mathrm{df}=$ $21,45, p<.003)$. Following treatment with $15 \mathrm{mg} / \mathrm{kg} / \mathrm{d}$ a significant main effect of PCP was observed $(\mathrm{F}=16.5$, $\mathrm{df}=1,12, p<.002)$ along with a PCP treatment $\times$ time interaction $(\mathrm{F}=10.0, \mathrm{df}=1.8,60, p=.001)$.

Treatment with $15 \mathrm{mg} / \mathrm{kg} / \mathrm{d}$ PCP also led to significant reductions in HVA levels (Figure 2C) as reflected by a significant main effect of PCP $(\mathrm{F}=4.83, \mathrm{df}=1,12$, $p<.05)$ and a significant PCP treatment $\times$ time interaction $(\mathrm{F}=3.1 \mathrm{df}=2.7,72, p<.05)$. Summed DOPAC and HVA levels during the 0-210-min interval were significantly lower following treatment with $15 \mathrm{mg} /$ $\mathrm{kg} / \mathrm{d}$ PCP than in controls (Figures $2 \mathrm{~B}$ and $2 \mathrm{C}$ ).

\section{Behavior}

Prior to PCP treatment, amphetamine showed a marked increase in locomotor activity starting $30 \mathrm{~min}$ after injection, and returning to baseline at $150-180 \mathrm{~min}$ following injection (Figure 3A). Following PCP treatment, amphetamine-induced activity was significantly enhanced, leading to significant PCP $\times$ time interaction following treatment with either $10(\mathrm{~F}=2.93, \mathrm{df}=7,48$, $p=.01)$ or $15(\mathrm{~F}=2.59, \mathrm{df}=7,48, p=.025) \mathrm{mg} / \mathrm{kg} /$ day PCP (Figure 3B). Summed activity during the 0-210min interval was significantly greater in animals treated with $15 \mathrm{mg} / \mathrm{kg} / \mathrm{d}$ PCP than in controls (Figure 4B). In

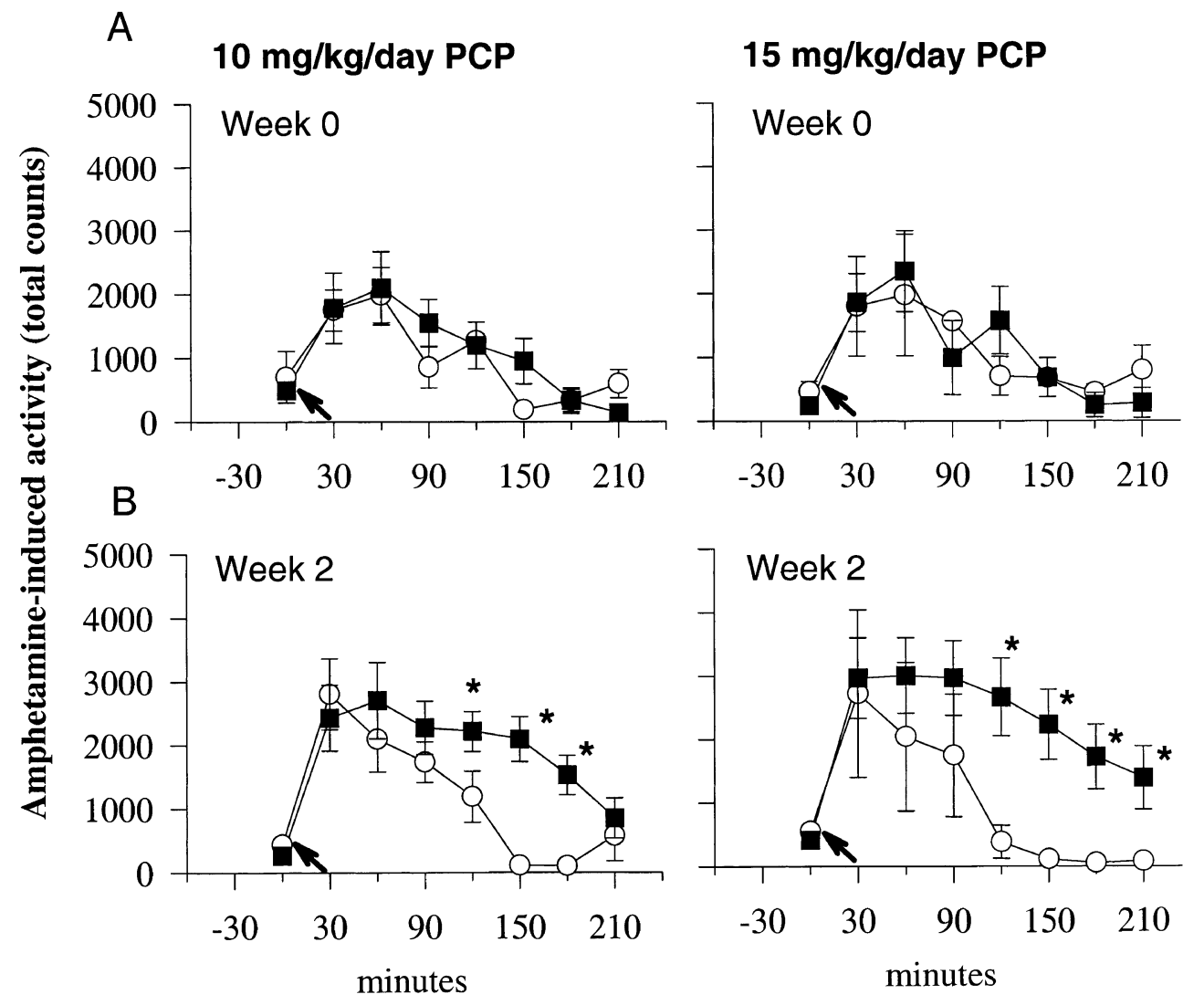

Figure 3. Amphetamineinduced total locomotor activity prior to (top) and following (bottom) a 2-week treatment with PCP (filled square) or saline (open circle). ${ }^{*} p<.05$ vs. saline. 
contrast to effects on amphetamine-induced activity, continuous PCP treatment did not alter spontaneous locomotor activity measured at the time of maximal normal activity (8 p.m.-8 a.m.) (Figure 4A).

\section{DISCUSSION}

One of the hallmarks of schizophrenia is an increase in the responsiveness of subcortical dopamine release to amphetamine administration, which has been demonstrated repeatedly in vivo in unmedicated subjects (Breier et al. 1997; Abi-Dargham et al. 1998; Laruelle et al. 1996). NMDA receptors are known to play a critical role in regulation of striatal dopamine release. It has been postulated that dopaminergic dysregulation in schizophrenia may reflect disturbed NMDA receptormediated neurotransmission.

The major finding of the present study is that following two weeks of continuous PCP treatment, basal dopamine levels in striatum are unchanged whereas amphetamine-induced stimulation of striatal dopamine release is markedly enhanced. PCP effects, moreover, are dose-related and occur at serum levels known to be associated with clinical psychosis. Further, although high concentrations of PCP may interact with dopamine transport and other receptor sites, the concentrations of PCP observed in the present study are associated with selective NMDA receptor inhibition (Javitt and Zukin 1991). Furthermore, dopamine transport blockade typically decreases amphetamine-induced dopamine release, as opposed to the increase observed in the present study.

Only one other study has investigated effects of subchronic PCP administration on dopamine metabolism and locomotor activity in rodents (Jentsch et al. 1998). In that study, subchronic intermittent administration induced an augmented locomotor response to stress and amphetamine administration. This behavior was associated with reduced dopamine utilization in the prefrontal cortex as evaluated using tissue dopamine and DOPAC measures. However, no differences in dopamine utilization in ventral striatum (nucleus accumbens) were observed at baseline. Enhanced nucleus accumbens dopamine release to amphetamine administration was inferred based upon the enhanced locomotor activity, but was not directly assessed using dopamine or metabolite measurements.

The present study supports the observation of enhanced subcortical dopamine release and enhanced locomotor activity following continuous NMDA antagonist administration. Whether the two processes are related, however, remains to be determined. In the present study, PCP treatment did not affect baseline extracellular DA levels. However the ability of dialysis to detect differences in baseline levels may be limited in the absence of a no net flux analysis.

Mechanisms underlying the present effect of PCP on amphetamine-induced hyperactivity cannot be fully evaluated from the present study. PCP, when given acutely, increases DOPAC and HVA levels along with those of dopamine (Javitt et al. 1999), whereas in the
A
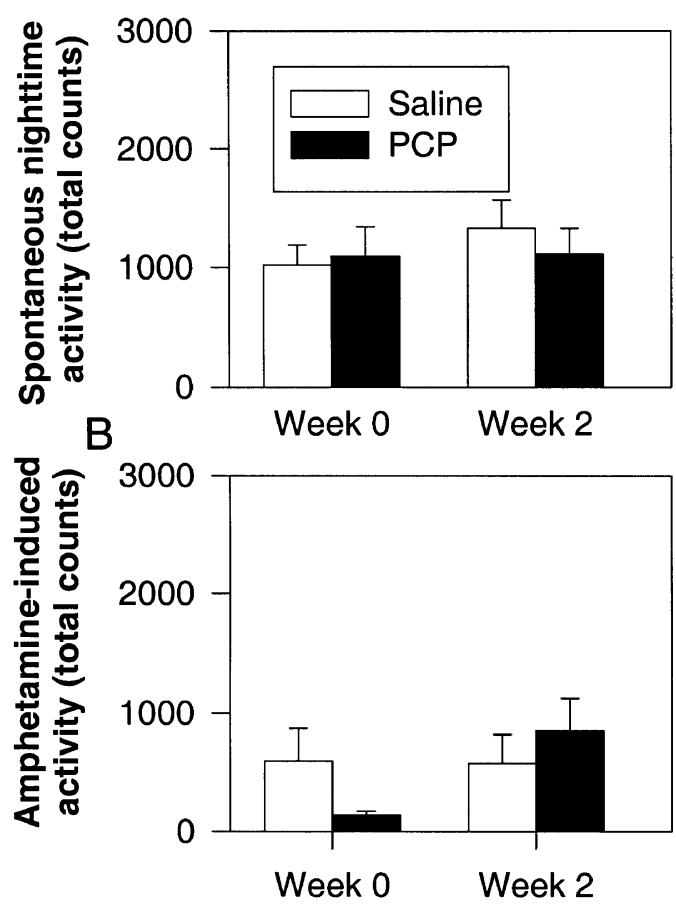

$10 \mathrm{mg} / \mathrm{kg} / \mathrm{d}$
$15 \mathrm{mg} / \mathrm{kg} / \mathrm{d}$
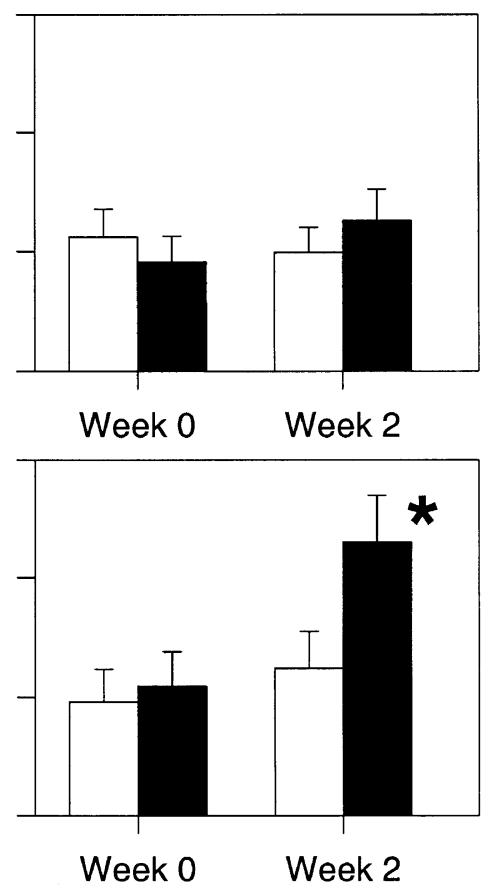

Figure 4. Bar graphs showing summed spontaneous nighttime activity (top) and amphetamineinduced activity (bottom) prior to and following PCP (filled square) or saline (open circle) administration. 
present study PCP treatment led to an exaggerated decrease in DOPAC and HVA levels. Thus, the enhanced release cannot be attributed to direct effects of PCP on dopamine release, but rather represents PCP-induced enhancement of amphetamine effects mediated, most likely, via NMDA blockade. NMDA receptors are known to exert multiphasic effects on striatal dopamine release. NMDA receptors located on presynaptic dopaminergic terminals stimulate dopamine release in a PCP-reversible fashion, whereas NMDA receptors on local GABAergic inhibitory neurons exert feedback inhibition of dopamine release (Whitton 1997). Although both effects may be observed in vivo, it has been proposed the presynaptic excitatory effects are of limited relevance under physiological conditions, while the inhibitory effects predominate (Carrozza et al. 1992).

We have recently observed that glycine, an NMDA agonist, inhibits dopamine release from striatal slices (Javitt et al. 2000), consistent with the concept that the primary action of striatal NMDA receptors is to negatively modulate striatal dopamine release. A potential site of PCP action in the present study, therefore, is on inhibitory feedback neurons within striatum. However, it has also been observed that acutely administered MK801 does not stimulate dopamine release elicited by locally administered amphetamine in striatum (Miller and Abercrombie 1996). Thus, inhibitory effects of NMDA antagonists on striatal dopamine release may not be mediated locally within striatum but may require intact striatonigral circuitry. In support of this hypothesis, PCP and MK- 801 have both been shown to increase the firing rate of nigrostriatal neurons, an effect that would lead to enhanced striatal dopamine release (White et al. 1995).

Subchronic, intermittent dose PCP treatment is reported to lead to upregulation of NR1 subunit expression in striatum (Hanania and Johnson 1999). To the extent that NMDA receptor upregulation occurs, it would be expected to mitigate effects of chronic PCP treatment and thus might account for the return of basal dopamine levels to baseline following subchronic administration. Effects of subchronic PCP treatment on dopamine synthesis or dopamine transporter expression also cannot be excluded, although continuous PCP treatment does not affect D2 levels in striatum(Robertson 1983).

In summary, the present study demonstrates that continuous PCP treatment for two weeks in rodents leads to enhanced striatal dopaminergic sensitivity to amphetamine administration. This preparation may serve as an appropriate animal model for pharmacological development in schizophrenia.

\section{ACKNOWLEDGMENTS}

Supported in part by USPHS grants R01 DA03383 and K02 MH01439 to D.C.J. and funding from the Stanley Foundation and NARSAD. We acknowledge the assistance of Noshin Chowdhury in post-mortem tissue preparation and immunocytochemical analysis.

\section{REFERENCES}

Abi-Dargham A, Gil R, Krystal J, Baldwin RM, Seibyl JP, Bowers $\mathrm{M}$, van Dyck CH, Charney DS, Innis RB, Laruelle M (1998): Increased striatal dopamine transmission in schizophrenia: Confirmation in a second cohort. Am J Psychiatry 155:761-767

Breier A, Su TP, Saunders R, Carson RE, Kolachana BS, de Bartolomeis A, Weinberger DR, Weisenfeld N, Malhotra AK, Eckelman WC, Pickar D (1997): Schizophrenia is associated with elevated amphetamine-induced synaptic dopamine concentrations: Evidence from a novel positron emission tomography method. Proc Natl Acad Sci U S A 94:2569-2574

Breier A, Adler CM, Weisenfeld N, Su TP, Elman I, Picken L, Malhotra AK, Pickar D (1998): Effects of NMDA antagonism on striatal dopamine release in healthy subjects: Application of a novel PET approach. Synapse 29:142147

Carrozza DP, Ferraro TN, Golden GT, Reyes PF, Hare TA (1992): In vivo modulation of excitatory amino acid receptors: Microdialysis studies on $N$-methyl-D-aspartate-evoked striatal dopamine release and effects of antagonists. Brain Res 574:42-48

Davis KL, Kahn RS, Ko G, Davidson M (1991): Dopamine in schizophrenia: A review and reconceptualization. A J Psychiatry 148:1474-1486

Domino E, Luby E (1981): Abnormal mental states induced by phencyclidine as a model of schizophrenia. PCP (Phencyclidine): Historical Current Perspect 401-418

Druhan JP, Rajabi H, Stewart J (1996): MK-801 increase locomotor activity without elevating extracellular dopamine levels in the nucleus accumbens. Synapse 24:135146

Gandolfi O, Rimondini R, Dall'Olio R (1992): The modulation of dopaminergic transmission in the striatum by MK-801 is independent of presynaptic mechanisms. Neuropharmacology 31:1111-1114

Hanania T, Johnson KM (1999): Regulation of NMDA-stimulated [14C]GABA and [3H]acetylcholine release by striatal glutamate and dopamine receptors. Brain Res 844:106-117

Hiramatsu M, Cho AK, Nabeshima T (1989): Comparison of the behavioral and biochemical effects of the NMDA receptor antagonists, MK-801 and phencyclidine. Eur J Pharmacol 166:359-366

Javitt DC (1987): Negative schizophrenic symptomatology and the phencyclidine (PCP) model of schizophrenia. Hillside J Clin Psychiatry 9:12-35

Javitt DC, Jotkowitz A, Sircar R, Zukin SR (1987): Non-competitive regulation of phencyclidine/å-receptors by the N-methyl-D-aspartate receptor antagonist D(-)2-amino5-phosphonovaleric acid. Neurosci Lett 78:193-198

Javitt DC, Zukin SR (1991): Recent advances in the phencyclidine model of schizophrenia. Am J Psychiatry 148: 1301-1308 
Javitt DC, Balla A, Sershen H, Lajtha A (1999): Reversal of phencyclidine-induced effects by glycine and glycine transport inhibitors. Biol Psychiatry 45:668-679

Javitt DC, Sershen H, Hashim A, Lajtha A (2000): Inhibition of striatal dopamine release by glycine and glycyldodecylamide. Brain Res Bull 52:213-216

Jentsch JD, Taylor JR, Roth RH (1998): Subchronic phencyclidine administration increases mesolimbic dopaminergic system responsivity and augments stress- and psychostimulant-induced hyperlocomotion. Neuropsychopharmacology 19:105-113

Jentsch JD, Roth RH (1999): The neuropsychopharmacology of phencyclidine: From NMDA receptor hypofunction to the dopamine hypothesis of schizophrenia. Neuropsychopharmacology 20:201-225

Kashihara K, Okumura K, Onishi M, Saburo O (1991): MK801 fails to modify the effect of methamphetamine on dopmaine release in the rat striatum. Neuroreport 2:236-238

Laruelle M, Abi-Dargham A, van Dyck CH, Gil R, D'Souza CD, Erdos J, McCance E, Rosenblatt W, Fingado C, Zoghbi SS, Baldwin RM, Seibyl JP, Krystal JH, Charney DS, Innis RB (1996): Single photon emission computerized tomography imaging of amphetamine- induced dopamine release in drug-free schizophrenic subjects. Proc Natl Acad Sci U S A 93:9235-9240

Laruelle M, Abi-Dargham A, Gil R, Kegeles LS, Innis R (1999): Increased dopamine transmission in schizoprenia: Relationship to illness phases. Biol Psychiatry 46:56-72

Lillrank SM, O'Connor WT, Saransaari P, Ungerstedt U (1994): In vivo effects of local and systemic phencyclidine on the extracellular levels of catecholamines and transmitter amino acids in the dorsolateral striatum of anaesthetized rats. Acta Physiol Scand 150:109-115

Linn GS, O'Keeffe RT, Schroeder CE, Lifshitz K, Javitt DC (1999): Behavioral effects of chronic phencyclidine in monkeys. Neuroreport 10:2789-2793

Luby ED, Cohen BD, Rosenbaum F, Gottlieb J, Kelley R (1959): Study of a new schizophrenomimetic drug, Sernyl. Arch Neurol Psychiatry 81:363-369

Luby ED, Gottlieb JS, Cohen BD, Rosenbaum G, Domino EF (1962): Model psychoses and schizophrenia. Am J Psychiatry 119:61-67

Miller D, Abercrombie E (1996): Effects of MK-801 on spontaneous and amphetamine-stimulated dopamine release in striatum measured with in vivo microdialysis in awake rats. Brain Res Bull 40:57-62

Newcomer JW, Farber NB, Jevtovic-Tedorovic V, Selke G,
Melson AK, Hershey T, Carft S, Olney JW (1999): Ketamine-induced NMDA receptor hypofunction as a model of memory impairment and psychosis. Neuropsychopharmacology 20:106-118

Nishijima K, Kashiwa A, Hashimoto A, Iwama H, Umino A, Nishikawa T (1996): Differential effects of phencyclidine and methamphetamine on dopamine metabolism in rat frontal cortex and striatum as revealed by in vivo dialysis. Synapse 22:304-312

Olney JW, Farber NB (1995): Glutamate receptor dysfunction in schizophrenia. Arch Gen Psychiatry 52:998-1007

Paxinos G, Watson C (1998): The Rat Brain in Stereotaxic Coordinates. Sydney, Academic Press

Robertson HA (1983): Chronic D-amphetamine and phencyclidine: effects on dopamine agonist and antagonist binding sites in the extrapyramidal and mesolimbic systems. Brain Res 267:179-182

Sams-Dodd F (1998): Effects of continuous D-amphetamine and phencyclidine administration on social behaviour, stereotyped behaviour, and locomotor activity in rats. Neuropsychopharmacology 19:18-25

Sams-Dodd F (1999): Phencyclidine in the social interaction test: an animal model of schizophrenia with face and predictive validity. Rev Neurosci 10:59-90

Sripada S, Gaytan O, Al-rahim S, Swann A, Dafny N (1998): Dose-related effects of MK-801 on acute and chronic methylphenidate administration. Brain Res 814:78-85

Stein L, Wise CD (1971): Possible etiology of schizophrenia: Progressive damage to the noradrenergic reward system by 5-hydroxydopamine. Science 171:10332-10336

Turgeon SM, Roche JK (1999): The delayed effects of phencyclidine enhance amphetamine-induced behavior and striatal C-Fos expression in the rat. Neuroscience 91:1265-75

Walberg CB, McCarron MM, Schulze BN (1983): Quantitation of phencyclidine in serum by enzyme immunoassay: results in 405 patients. J Anal Toxicol 7:106-110

White IM, Flory GS, Hooper KC, Speciale J, Banks DA, Rebec GV (1995): Phencyclidine-induced increases in striatal neuron firing in behaving rats: Reversal by haloperidol and clozapine. J Neural Transm Gen Sect 102:99-112

Whitton PS (1997): Glutamatergic control over brain dopamine release in vivo and in vitro. Neurosci Biobehav Rev 21:481-488

Yonezawa Y, Kuroki T, Tashiro N, Hondo H, Uchimura H (1995): Potentiation of phencyclidine-induced dopamine release in the rat striatum by the blockade of dopamine D2 receptor. Eur J Pharmacol 285:305-308 